\title{
Repayment Behavior and Default Position of Credit Availed Farmers: An empirical Study from Nayagarh District of Odisha, India
}

\author{
Surya Sidhant Rath*, Rajkishore Mishra and Sarba Narayan Mishra \\ Department of Agricultural Economics, College of Agriculture, Orissa University of \\ Agriculture and Technology, Bhubaneswar, Odisha-751003, India \\ *Corresponding author
}

\begin{tabular}{l} 
K e y w o r d s \\
$\begin{array}{l}\text { Credit, } \\
\text { Cooperatives, } \\
\text { Recovery, 3Rs, 5Cs } \\
\text { and 7Ps }\end{array}$ \\
\hline Article Info \\
\hline $\begin{array}{l}\text { Accepted: } \\
\text { 10 April } 2020 \\
\text { Available Online: } \\
\text { 10 May } 2020\end{array}$ \\
\hline \hline
\end{tabular}

\section{A B S T R A C T}

Efficient utilization of credit and prompt repayment go hand in hand. If the credit is utilized properly then there is every possibility of having good returns, which in turn can help to repay the loan in time and timely repayment helps the borrower to get escape from the debt trap and acquire the benefit of interest subvention provided by the government. An endeavor is herein made to study the recovery performance of financial institutions which was designed through a random sample survey of hundred credit availed farmers in the diverse agriculture terrains of Nayagarh district and analyzed by descriptive statistics. Out of the hundred respondents twenty seven respondents are the defaulters. The Cooperatives have better recovery performance than commercial banks and RRBs. This non-repayment scenario is owing to lack of post disbursement following up. Most of the borrowers (seventy three per cent) fully repaid to build trustworthiness, to avail future loan and for non-repayment, some of the borrowers are willfull defaulters and some have genuine issue for being defaulters i.e. crop failure. Strictly assessing economic feasibility through credit worthiness tests i.e. $3 \mathrm{Rs}, 5 \mathrm{Cs}$ and $7 \mathrm{Ps}$ by the banker before credit disbursement may help to assure prompt repayment.

\section{Introduction}

Agriculture, along with the allied sectors is undoubtedly the largest livelihood provider in India, to a vast extent in the rural areas. Modern farming is no less than a business. In the changing world, farm business has thus become more competitive. Success in agriculture largely depends on appropriate combination of money, management and marketing. Very often, the money for farming comes in the form of credit. Hence the real success of agriculture depends on efficient utilization and prompt repayment by the credit borrowers.

In every activity, there should be a delicate balance about right quantity of every aspect. For example, a farmer is well aware about the effects of applying fertilisers in scarce amount 
or in abundance. Similar is the case with credit. Credit has also its pros and cons. It is worth noting that credit should be used up to the right amount. Hence, aptly used credit is a valuable tool. Efficient utilization of credit and prompt repayment go hand in hand. If the credit is utilized properly then there is every possibility of having good returns, which in turn can help to repay the loan in time.

Timely repayment of the loans is an essential factor responsible for the judicious development of funds by the financial institutions. When the recovery performance is good for the financial institutions it will help them to recycle further their limited and scarce funds. On the contrary, a poor performance in recovery would jeopardize the progress of such institutions by making them ineligible to obtain fresh finance from the refinancing agencies. Not only this is the case but also a timely repayment helps the borrower to get escape from the debt trap and acquire the benefit of interest subvention provided by the government.

Hence it is with this background that the current study attempts to scrutinize the repayment behavior of the sample farmers in the study area.

\section{Materials and Methods}

Nayagarh district in the state of Odisha was purposively selected for the study. The sampling procedure followed here for the study was multi staged random sampling method. On the first stage, Nayagarh block was randomly selected.

On the second stage out of the twenty nine gram panchayats in Nayagarh block, one third (ten) of them were selected randomly that would represent the entire block. Such panchayats were Balugaon, Champatipur, Badapandusar, Biruda, Bhattasahi, Lenkudipada, Kalikaprasad, Lathipada, Nabaghanapur, Sinduria. Here all possible institutional agencies have financed.

In the third stage, all the households of ten Gram Panchayats, availed loan from institutional agencies, were listed and ten households were taken from each GP randomly. Head of the household was the respondent. The farm holdings were classified in three size groups as:

Group-I: Marginal farmers (<2.5acres)

Group-II: Small farmers (2.5-5acres)

Group-III: Large farmers (> 5acres)

It was seen in all the Panchayats that nearly sixty per cents farmers belonged to Group-I category while thirty five percent from Group-II and rest from Group-III category. From each panchayat ten households were take randomly that comprised of six marginal farmers, three small farmers, and one large farmer.

\section{Selection of sample respondents:}

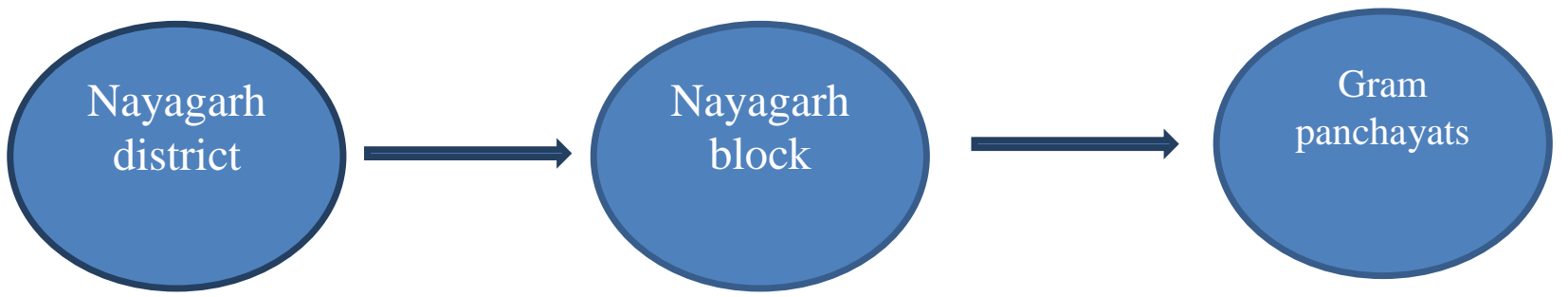




\begin{tabular}{|l|c|c|c|c|}
\hline \multicolumn{1}{|c|}{ CATEGORY } & Group-I & Group-II & Group-III & Total \\
\hline Balugaon & & & & \\
\hline Champatipur & 6 & 3 & 1 & 10 \\
\hline Badapandusar & 6 & 3 & 1 & 10 \\
\hline Biruda & 6 & 3 & 1 & 10 \\
\hline Bhattasahi & 6 & 3 & 1 & 10 \\
\hline Lenkudipada & 6 & 3 & 1 & 10 \\
\hline Kalikaprasad & 6 & 3 & 1 & 10 \\
\hline Lathipada & 6 & 3 & 1 & 10 \\
\hline Nabaghanapur & 6 & 3 & 1 & 10 \\
\hline Sinduria & 6 & 3 & 1 & 10 \\
\hline \multicolumn{1}{r|}{ Total } & 60 & 30 & 10 & 100 \\
\hline
\end{tabular}

Thus in this way hundred households i.e. sixty from Group-I, thirty from Group-II and ten from Group-III were selected from the block for the present study.

Primary data were collected from the sample farmers using a pre tested structured interview schedule. The finalised schedule sought detailed information on sources and supply of farm credit etc. In addition, interview technique was also used to extract detailed information wherever needed for open end questions with the bank officials at the state and district level. The information provided by the respondents related to input and output of the agriculture sector was related to the agricultural year 2018-19.

Descriptive data analysis technique was solely used to provide valuable information about the basic feature of the data in the study. With this technique, the estimates and summaries were arranged in tables, to meet the objective. To be very specific, the technique was used to describe what is and what the data shows.

\section{Results and Discussion}

Down the years, it has been quite a challenging and tough task for the bankers to prevent NPAs and encourage prompt repayment for the borrowers. Before analyzing the repayment and default position, let us have a quick glance on the sources and amount of credit borrowed.

\section{Sources of credit}

Table 1 represents the sources of farm credit for the sample respondents. Commercial banks, Regional Rural Banks and Cooperatives are the various sources of credit for the sample respondents in the study area. Group-I respondents have maximally borrowed from cooperatives while Group-III respondents have completely relied upon commercial banks. RRBs have only contributed to the Group-I respondents. All the three sources of credit have catered to the credit needs of Group-I respondents. Majority of the Group-II respondents i.e. eighty per cent are dependent on commercial banks and 
rest of the respondents on cooperatives. So in a decreasing tune, forty four respondents met their credit need from cooperatives followed by thirty nine from commercial banks and rest of the respondents from the RRBs.

\section{Average amount of credit borrowed}

Table 2 points out the average amount of credit borrowed from different sources by the sample respondents. The credit borrowed by the sample respondents of Group-I from different sources is almost at par. The average amount borrowed by a sample respondent of Group-II from commercial bank is nearly seventy five thousand rupees while from cooperatives, it is nearly seventy one thousand. A Group-III respondent borrows eighty six thousand rupees. So as a whole the average amount borrowed by a respondent from commercial bank is twenty eight thousand four hundred thirty two rupees while eighteen thousand six hundred twenty rupees from Cooperatives and only six thousand two hundred rupees from RRBs.

The repayment attitude of the sample respondents in the study area is presented under the following sub-heads:

1. Repayment scenario

2. Default position

\section{Repayment scenario}

The repayment scenario of the sample respondents is presented in Table 3 and it shows that there is no amount outstanding at the beginning of the year for the Group-I respondents. It is because there is no repayment and subsequent issue of fresh loan in cooperative banks. Only the interest amount is paid. For this, during the interaction, most of the Cooperative Secretaries confidently stated that they had almost hundred per cent recovery.

But it is also seen that during the current year some of the credit availing respondents from Group-I have outstanding dues. But it may be noted that Group-I respondents have also availed credit from RRBs and Commercial Banks.

However Group-II respondents and Group-III respondents availing credit from commercial banks are seen to have outstanding amount, as there is the need to repay the entire loan amount with seven per cent rate of interest though the subsidised value of interest rate is imbursed on their account later on.

Table.1 Sources of credit for the sample respondents $(n=100)$

\begin{tabular}{|l|l|l|l|l|l|l|l|}
\hline SI. No. & Category & \multicolumn{2}{|l|}{ Commercial banks } & RRBs & \multicolumn{2}{l|}{ Cooperatives } \\
\cline { 3 - 8 } & Number & $\%$ & Number & $\%$ & Number & $\%$ \\
\hline $\mathbf{1}$ & $\begin{array}{l}\text { Group-I } \\
\left(\mathbf{n}_{1}=\mathbf{6 0}\right)\end{array}$ & 5 & 8.3 & 17 & 28.3 & 38 & 63.3 \\
\hline $\mathbf{2}$ & $\begin{array}{l}\text { Group-II } \\
\left(\mathbf{n}_{2}=\mathbf{3 0}\right)\end{array}$ & 24 & 80 & 0 & 0 & 6 & 20 \\
\hline $\mathbf{3}$ & $\begin{array}{l}\text { Group- } \\
\text { III } \\
(\mathbf{n}=\mathbf{1 0})\end{array}$ & 10 & 10 & 0 & 0 & 0 & 0 \\
\hline $\mathbf{4}$ & $\begin{array}{l}\text { Total } \\
(\mathbf{n = 1 0 0})\end{array}$ & 39 & 39 & 17 & 17 & 44 & 44 \\
\hline
\end{tabular}


Table.2 Average amount of credit borrowed from different sources by the samplerespondents $(n=100)$

(inRs)

\begin{tabular}{|c|c|c|c|c|}
\hline Sl. No. & Category & Commercial banks & RRBs & Cooperatives \\
\hline $\mathbf{1}$ & $\begin{array}{c}\text { Group-I } \\
\left(\mathbf{n}_{\mathbf{1}}=\mathbf{6 0}\right)\end{array}$ & 35600 & 36517 & 37815 \\
\hline $\mathbf{2}$ & $\begin{array}{c}\text { Group-II } \\
\left(\mathbf{n}_{\mathbf{2}}=\mathbf{3 0}\right)\end{array}$ & 74966 & 0 & 70833 \\
\hline $\mathbf{3}$ & $\begin{array}{c}\text { Group-III } \\
\left(\mathbf{n}_{\mathbf{3}}=\mathbf{1 0}\right)\end{array}$ & 86600 & 0 & 0 \\
\hline $\mathbf{4}$ & $\begin{array}{c}\text { Pooled } \\
(\mathbf{n = 1 0 0})\end{array}$ & 46693 & 21910 & 43939 \\
\hline
\end{tabular}

Table.3 Repayment performance of the sample respondents $(n=100)$

\begin{tabular}{|l|l|l|l|l|l|}
\hline SI. No. & Category & $\begin{array}{l}\text { Amount } \\
\text { outstanding at the } \\
\text { beginning of the } \\
\text { year }\end{array}$ & $\begin{array}{l}\text { Amount } \\
\text { borrowed } \\
\text { during the } \\
\text { year }\end{array}$ & $\begin{array}{l}\text { Amount } \\
\text { repaid } \\
\text { during the } \\
\text { year }\end{array}$ & $\begin{array}{l}\text { Amount } \\
\text { outstanding } \\
\text { at the end of } \\
\text { the year }\end{array}$ \\
\hline $\mathbf{1}$ & $\begin{array}{l}\text { Group-I } \\
\text { (n=60) }\end{array}$ & 0 & 37250 & 27480 & 10130 \\
\hline $\mathbf{2}$ & $\begin{array}{l}\text { Group-II } \\
\text { (n=30) }\end{array}$ & 2223.3 & 74133.3 & 58126.6 & 20656.6 \\
\hline $\mathbf{3}$ & $\begin{array}{l}\text { Group-III } \\
\left(\mathbf{n}_{\mathbf{3}}=\mathbf{1 0}\right)\end{array}$ & 3030 & 86600 & 78690 & 14900 \\
\hline $\mathbf{4}$ & $\begin{array}{l}\text { Pooled } \\
\text { (n=100) }\end{array}$ & 970 & 53250 & 41794.7 & 13765.5 \\
\hline
\end{tabular}

Table.4 Number of defaulters among sample respondents $(n=100)$

\begin{tabular}{|l|l|c|c|}
\hline SI No & Category & \multicolumn{2}{|c|}{ Defaulters } \\
\cline { 2 - 4 } & & Number & \% \\
\hline $\mathbf{1}$ & $\begin{array}{l}\text { Group-I } \\
\left(\mathbf{n}_{1}=\mathbf{6 0}\right)\end{array}$ & 16 & 26.6 \\
\hline $\mathbf{2}$ & $\begin{array}{l}\text { Group-II } \\
\left(\mathbf{n}_{\mathbf{2}}=\mathbf{3 0}\right)\end{array}$ & 8 & 26.6 \\
\hline $\mathbf{3}$ & $\begin{array}{l}\text { Group-III } \\
\left(\mathbf{n}_{\mathbf{3}}=\mathbf{1 0}\right)\end{array}$ & 3 & 30 \\
\hline $\mathbf{T o t a l}$ & 27 & 27 \\
\hline $\mathbf{n}=\mathbf{1 0 0})$ & & 27 \\
\hline
\end{tabular}


Table.5 Reasons of default of the sample respondents $(n=100)$

\begin{tabular}{|l|l|l|c|c|c|c|}
\hline $\begin{array}{l}\text { Sl. } \\
\text { No. }\end{array}$ & Category & $\begin{array}{l}\text { Crop } \\
\text { failure }\end{array}$ & $\begin{array}{l}\text { Inadequacy of } \\
\text { loan amount }\end{array}$ & Diversion & $\begin{array}{l}\text { Political } \\
\text { factors }\end{array}$ & Total \\
\hline $\mathbf{1}$ & $\begin{array}{l}\text { Group-I } \\
\left(\mathbf{n}_{\mathbf{1}}=\mathbf{6 0}\right)\end{array}$ & $7(43.75 \%)$ & $5(31.25 \%)$ & $3(18.75 \%)$ & $1(6.25 \%)$ & 16 \\
\hline $\mathbf{2}$ & $\begin{array}{l}\text { Group-II } \\
\left(\mathbf{n}_{2}=\mathbf{3 0}\right)\end{array}$ & 0 & 0 & $3(37.5 \%)$ & $5(62.5 \%)$ & 8 \\
\hline $\mathbf{3}$ & $\begin{array}{l}\text { Group-III } \\
\left(\mathbf{n}_{3}=\mathbf{1 0}\right)\end{array}$ & 0 & 0 & $3(100 \%)$ & 0 & 3 \\
\hline $\mathbf{4}$ & $\begin{array}{l}\text { Total } \\
(\mathbf{n}=\mathbf{1 0 0})\end{array}$ & $7(25.93 \%)$ & $5(18.5)$ & $9(33.3 \%)$ & $6(22.2 \%)$ & 27 \\
\hline
\end{tabular}

Similar is the case with RRBs. So it can be said that Cooperatives have better recovery performance than commercial banks and RRBs. This non-repayment scenario is owing to lack of post disbursement follow up. Similar findings were reported by Narendra and Gosavi in 2005 while examining recovery performance of Maharashtra banks.

\section{Default position}

The number of the defaulters and the reasons of being default among the sample respondents have been presented in the Table 4 and 5 respectively. There is almost equal proportion of defaulters from all the categories. Out of the hundred respondents twenty seven respondents are the defaulters.

From both the tables it could be observed that some of the Group I respondents have crop failure and for some of the respondents the loan amount was inadequate. Few of them diverted and while only one respondent thought about waiving of farm loan due to ongoing election of 2019. Most of the GroupII respondents have the same notion of loan waiving.

This is akin to the findings of Singh and Shah in 2004 regarding repayment attitude of the borrowers of agriculture loan from Ranchi
Khetriya Gramin Bank in Jharkhandthat the farm loan may be waived off by the government at some time.

However the educated Group-III respondents didn't believe in it rather they were the defaulters for diverting the loan to other consumptive purposes.

Hence, to sum up, most of the borrowers fully repaid to build trustworthiness, to avail future loan and for non-repayment, some of the borrowers were will full defaulters and some had genuine issue for being defaulters.

Similar findings were reported by Virk et al., in 2003 while examining the credit recovery behavior of Punjab farmers.

As represented in Table 5,the reasons of being defaulters, respondents of different categories opine differently for reasons of default like crop failure, inadequacy of loan amount, diversion and political factors. Group-III respondents become defaulters only because they divert the loan amount for other purposes. Most of the Group-II respondents i.e. 62.5 per cent become defaulters for certain political biasness and rest for diversion for other activities. Among Group-I respondents there is a mixed reason for being defaulters. Crop failure (43.75 per cent) is the 
major problem for Group-I respondents followed by inadequacy of loan amount (31.25 per cent), diversion for other activities (18.75 per cent), and political factors (6.25 per cent). Out of the twenty seven defaulters, most respondents are unable to repay because they divert the loan amount for some other purposes.

Based on the findings of the study, the following policies are suggested in the study area to reduce the credit overdues and to ensure easy recovery of farm credit.

Strictly assessing economic feasibility through credit worthiness tests i.e. 3Rs, 5Cs and 7Ps by the banker before credit disbursement to assure prompt repayment and the bankers should not allow the interference of any private intermediaries in the lending process.

Arrangement for hassle free settlement of disputed overdue cases.

Stringent legal action may be inflected against the willful defaulters.

Post credit disbursement follows up by the bank officials in association with the Department of Agricultural officials need to be undertaken

Awareness camps in every village or Village Panchayats need to be organized by the NABARD officials or Lead Banks officials or any officials directed by them in frequent intervals to make them familiar about the benefits of timely repayment of the farm credit.

A timely and need based support in creation of quality asset will lead to the overall economic growth of the block as well as the district and ramify business of the banks.

\section{References}

Chidambara K and Ganesan S. 2002. Overdue in Primary Agriculture Cooperative Banks in Madurai district of Tamil Nadu: A study. Cooperative Perspective.37(3): 57-64.

Gandhimati S and Vanitha S. 2010. Determinants of borrowing behavior of farmers : A comparative study of commercial and cooperative banks. Agriculture Research Review.23: 157164

Khatun MN, Milan MRU and Khatun MA. 2014. Credit utilization and repayment behaviour of the farmers: An empirical study from Kushtia district of Bangladesh. J. SylhetAgril. Univ. 1(2): 279-287.

Narendra B and Gosavi 2005.Recovery performance of Maharastra State Cooperative Agriculture and Rural Multipurpose Development Bank. Cooperative Perspective.39(4): 59-67.

Rath SS. 2019. Utilization and efficiency of Agricultural credit in Nayagarh block of Nayagarh district, M.Sc. Ag thesis, OUAT, Odisha

Shivappa H. 2005. Agriculture credit utilization pattern and its repayment performance of borrowers of Regional Rural Banks in Karnataka. A case study of Chitradurga Grameena Bank. Indian Journal of Agricultural Economics.60(3): 366

Singh AK Khosta AK and Chandrakara MR. 2004.Avaialability, Utilisation and Repayment of crop loan: A case study of rice growers under DCCB, Raipur, Chhatishgarh, Financing Agriculture. 41(2):139-148

Singh RP and shah AK. 2004. Repayment performance of borrowers with respect to agricultural loans of Ranchi Khetriya Gramin Bank: A micro analysis. Indian Journal of Agriculture Economics. 
60(3): 396.

Thomas KJ, Tomas EK and Thomas TT. 2005. Economic Feasibility and repayment capacity of borrowers of minor irrigation loans in Thrissur district of Kerala. Indian Cooperative
Review, 42(4): 350-355

Virk GS Kalra RK and Hansra S. 2003.Credit repayment behavior of Punjab farmers. Indian Journal of Extension Education. 39(1\&2): 12-17.

\section{How to cite this article:}

Surya SidhantRath, Rajkishore Mishra and Sarba Narayan Mishra. 2020. Repayment Behavior and Default Position of Credit Availed Farmers: An empirical Study from Nayagarh District of Odisha, India. Int.J.Curr.Microbiol.App.Sci. 9(05): 1138-1145.

doi: https://doi.org/10.20546/ijcmas.2020.905.124 